\title{
Changes in atrial natriuretic peptide concentrations during intravenous saline infusion in hypoxic cor pulmonale
}

A G Stewart, P A Bardsley, S V Baudouin, J C Waterhouse, J S Thompson, A H Morice, P Howard

\begin{abstract}
Background The pathogenesis of oedema in hypoxic cor pulmonale is poorly understood. One possibility is a failure of atrial natriuretic peptide release, leading to salt and water retention. This hypothesis was tested by observing the response to an intravenous saline challenge in patients with and without cor pulmonale.
\end{abstract}

Methods Plasma atrial natriuretic peptide concentrations were measured before and for three hours after an intravenous saline load $(0.1 \mathrm{ml} \quad 2 \cdot 7 \%$ saline/kg/min for 60 minutes) in 20 patients with chronic obstructive airways disease. Ten patients with cor pulmonale, as judged clinically by the presence of peripheral oedema with a previously documented increase in the jugular venous pressure or pleural effusions during an acute exacerbation of airway obstruction (mean (SE) age 67 (3) years, FEV $0.73(0.08) 1$, arterial oxygen tension $\left(\mathrm{PaO}_{2}\right) 6.4(0.4) \mathrm{kPa}$, and arterial carbon dioxide tension $\left.\left(\mathrm{PaCO}_{2}\right) \quad 6.7(0.3) \mathrm{kPa}\right)$, were compared with 10 patients with hypoxic chronic obstructive airways disease who had never had oedema (mean age 63 (1) years, FEV $1.07(0.09) 1, \mathrm{PaO}_{2}$ 8.6 (0.4) kPa, and $\left.\mathrm{PaCO}_{2} 5 \cdot 3(0 \cdot 2) \mathrm{kPa}\right)$. All patients were studied fasting and after diuretics had been stopped for three days. No supplemental oxygen was given. Results The mean four hourly urine sodium excretion was less in the patients who had oedema $(27(4 \cdot 6) \mathrm{mmol}, 13 \%$ of the intravenous load) than in those without oedema $(82(15 \cdot 5) \mathrm{mmol}, 43 \%$ of the load). Initial mean plasma atrial natriuretic peptide values were significantly higher in the patients with cor pulmonale (19.1 (1.6) compared with 10.2 $(0.7) \mathrm{pmol} / \mathrm{l})$ and the mean peak rise in atrial natriuretic peptide after the intravenous saline load had been given was $13(8.0) \mathrm{pmol} / 1$ in the patients with cor pulmonale and $5.5(2.3) \mathrm{pmol} / 1$ in the controls. There were no significant differences in plasma and urinary osmolality, blood pressure, or creatinine clearance between the groups.

Conclusion Patients with chronic obstructive airways disease and cor pulmonale have an impaired ability to excrete a hypertonic intravenous saline load despite a normal physiological release of plasma atrial natriuretic peptide.

Atrial natriuretic peptide, a 28 amino acid hormone, is formed and stored in atrial myocytes and secreted predominantly into the right atrium in response to atrial stretch, as may occur with volume overload ${ }^{1}$ or tricuspid regurgitation. $^{2}$ Although plasma atrial natriuretic peptide concentrations are raised in chronic obstructive airways disease, the concentrations correlate poorly with pulmonary artery pressure. ${ }^{3}$ Atrial natriuretic peptide has potent natriuretic and diuretic actions and helps to regulate fluid balance. ${ }^{4}$

Patients with hypoxic chronic obstructive airways disease who develop oedema have a poor prognosis, $70 \%$ dying within five years. Cardiac output is usually normal or increased, ${ }^{6}$ renal blood flow is reduced, ${ }^{7}$ and excretion of water and salt loads is impaired. This defect in salt and water handling correlates strongly with the degree of hypercapnia; patients who are hypoxaemic but normocapnic are able to handle a salt and water load fairly normally. ${ }^{8}$

Abnormalities in antidiuretic hormone secretion and activation of the renin-aldosterone system have been found in patients with chronic obstructive airways disease and hypercapnia. Investigations by Farber et $a l^{8}$ sugggest that the ability to handle a salt load diminishes with the development of hypercapnia as a result of a reduction in renal blood flow. The onset of oedema is associated with stimulation of the renin-angiotensin-aldosterone axis and the antidiuretic hormone system. A raised aldosterone concentration may contribute to sodium retention and the increase in antidiuretic hormone to hyponatraemia. These changes could be due to a further reduction in renal blood flow in cor pulmonale rather than being a cause of the oedema.

Atrial natriuretic peptide has been reported to lower antidiuretic hormone levels ${ }^{9}$ and to antagonise the renin-angiotensinaldosterone system, ${ }^{10}$ reducing renin and aldosterone secretion and acting as a functional antagonist to aldosterone and angiotensin II. Although these actions do not play a part in acute natriuresis they may be important in the long term control of sodium balance.

In normal individuals acute volume expansion increases plasma atrial natriuretic peptide 
concentrations and causes natriuresis. ${ }^{11}$ To investigate whether a failure of atrial natriuretic peptide secretion or a lack of response to circulating atrial natriuretic peptide could underlie the fluid and sodium retention in patients with cor pulmonale, we compared basal concentrations of atrial natriuretic peptide and its response to an infusion of $2 \cdot 7 \%$ saline in patients with cor pulmonale and in patients with hypoxaemic chronic obstructive airways disease but no current or previous evidence of fluid retention or right heart failure.

\section{Methods \\ PATIENTS}

Ten patients with stable cor pulmonale (as judged clinically by the presence of peripheral oedema and a previously documented rise in the jugular venous pressure or pleural effusions or both) and 10 patients with hypoxaemic chronic obstructive airways disease with no previous or current history of oedema were chosen from patients attending the chest clinic. Patients with known heart disease, liver disease, renal disease, hormone disorder, or diabetes mellitus were excluded. Subjects ate a conventional diet and fasted overnight. Diuretics were stopped for three days before the study. The study was approved by the Ethical Committee of the Sheffield Health Authority. All patients gave consent freely after the aims and requirements of the study had been explained.

\section{MEASUREMENTS AND SAMPLES}

The patients were brought by taxi to the laboratory at 0900 hours and weighed. Spirometry (Vitalograph Compact) was performed and the patients then emptied their bladders, the urine being collected for measurement of osmolality and electrolytes. Blood pressure (sphygmomanometer), pulse rate, and arterial oxygen saturation (pulse oximeter, Ohmeda Biox 3700) were recorded. Patients remained seated throughout the salt load test.

Blood for determining urea and electrolyte concentrations (Technicon SMAC analyser) and osmolality (Advance osmometer 2WII) were collected into serum tubes and plasma for assay of atrial natriuretic peptide into tubes containing ethylenediaminetetra-acetate (EDTA). The EDTA tubes were centrifuged immediately and the plasma was removed and frozen at $-20^{\circ} \mathrm{C}$ until it was assayed. Samples were taken 30 minutes before and at the time of the saline infusion (time zero) and 60,120, 180, and 240 minutes afterwards. At time zero the subjects received $6 \mathrm{ml} / \mathrm{kg}$ intravenous $2 \cdot 7 \%$ (3N) saline $(450 \mathrm{mmol} / \mathrm{l})$ over 60 minutes (that is $0 \cdot 1 \mathrm{ml} / \mathrm{kg} / \mathrm{min}$ ). Blood pressure and arterial oxygen saturation were recorded at each time point. After four hours arterial blood gases were measured. The patients emptied their bladders, urine volume was noted, and the urinary excretion of sodium and creatinine and osmolality were measured.

CALCULATION OF CREATININE CLEARANCE

Creatinine clearance was calculated over the
$4 \cdot 5$ hours of the test and used as a measure of the glomerular filtration rate. Filtered sodium ( $\mathrm{mmol} / \mathrm{min}$ ) was calculated by multiplying the glomerular filtration rate by the plasma sodium concentration. Fractional sodium reabsorption was calculated by dividing excreted sodium ( $\mathrm{mmol} / \mathrm{min}$ ) by the filtered sodium and subtracting from 1 , the fraction being expressed as a percentage. Free water clearance was calculated from the average of the plasma osmolalities during the test (Posm) and the end urine osmolality (Uosm) and the minute urine volume (Uv) by means of the formula

$$
\begin{gathered}
\text { Free water clearance }= \\
\mathrm{Uv}-(\mathrm{Uosm} \times \mathrm{Uv} / \text { Posm }) .
\end{gathered}
$$

The negative value is the renal reabsorption of water in $\mathrm{ml} /$ minute.

\section{ATRIAL NATRIURETIC PEPTIDE ASSAY}

Initial extraction of plasma atrial natriuretic peptide was carried out with Sep-Pak C18 cartridges (Waters Associates). One millilitre of plasma acidified with trifluoroacetic acid $(0 \cdot 1 \%)$ was applied to a primed cartridge, washed with $5 \mathrm{ml} 0.15$ trifluoroacetic acid, and eluted with $2.5 \mathrm{ml}$ of $60 \%$ acetonitrile. Samples were vacuum dried and then reconstituted with $1 \mathrm{ml}$ of assay buffer (consisting of $40 \mathrm{mM}$ disodium hydrogen $o$-phosphate, $70 \mathrm{mM}$ sodium dihydrogen $o$-phosphate, $7 \mathrm{mM}$ sodium azide, $5 \mathrm{mM}$ ethylenediaminetetra-acetate, and $0.5 \%$ bovine serum albumin with the $\mathrm{pH}$ adjusted to $7 \cdot 4$ ). Aliquots of $100 \mathrm{ml}$ were assayed in duplicate. Assay incubations consisted of $100 \mu \mathrm{l}$ atrial natriuretic peptide labelled with iodine- 125 $(4000-6000 \mathrm{cpm} / 100 \mu \mathrm{l}), 100 \mu \mathrm{l}$ sheep polyclonal anti-atrial natriuretic peptide antibody, $200 \mu \mathrm{l}$ assay buffer, and $100 \mu \mathrm{l}$ buffer containing atrial natriuretic peptide standards or plasma extracts. Samples were incubated for four to five days at $4^{\circ} \mathrm{C}$. Separation of the bound and free fractions was achieved by adding $100 \mu \mathrm{l}$ $2 \% \mathrm{IgG}$ in assay buffer and $1 \mathrm{ml}$ polyethylene glycol (MW 6000) to each tube followed by centrifugation at $3500 \mathrm{rev} / \mathrm{min}$ for 45 minutes.

About $60 \%$ of the label was bound in the absence of the unlabelled peptide and $5-10 \%$ in the absence of antibody. The intra-assay coefficient of variation was $8.5 \%$ and the $95 \%$ confidence detection limit was $2.5 \mathrm{pmol} / 1$ of plasma.

\section{ANALYSIS}

Means and standard errors of the mean (SE) are given for group data. Groups are compared by a two sample (unpaired) $t$ test. Values of $\mathrm{p}$ below 0.05 are considered significant.

\section{Results}

Details of the patients are shown in table 1. All the patients with cor pulmonale were receiving long term oxygen therapy. None of the control group was having long term oxygen therapy, though two patients had intermittent oxygen. With the exception of prior diuretics, the pharmacological treatment was similar in the two groups. Two of the "non-oedematous" 
patients were taking diuretics; one had a diagnosis of hypertension and the other had had them prescribed by his general practitioner for breathlessness (without evidence of fluid retention).

The 10 patients (two female) with cor pulmonale had a similar mean (SE) age (67 (3) years) and weight $(81.7(6.2 \mathrm{~kg})$ as the 10 patients (three female) without cor pulmonale (age 63 (1) years and weight $66.74 .4 \mathrm{~kg}$ ); but the patients with cor pulmonale had a lower $\mathrm{FEV}_{1}(0.73(0.08) v 1.07(0.09) \mathrm{l} ; \mathrm{p}<0.05)$ and arterial oxygen tension $(6.4 \quad(0.4) \quad v \quad 8.6$ $(0.4) \mathrm{kPa} ; \mathrm{p}<0.01)$, and a higher arterial carbon dioxide tension $(6.7 \quad(0.3) \quad v \quad 5.3$ $(0.2) \mathrm{kPa} ; \mathrm{p}<0.01)$

Baseline serum sodium concentrations were similar in the two groups. The baseline urinary

Table 1 Details of the patients

\begin{tabular}{|c|c|c|c|c|c|c|c|}
\hline $\begin{array}{l}\text { Patient } \\
\text { No }\end{array}$ & $\begin{array}{l}\text { Age } \\
(y)\end{array}$ & $\begin{array}{l}\text { Weight } \\
\text { (kg) }\end{array}$ & $\begin{array}{l}\text { Diuretics* } \\
\text { (daily) }\end{array}$ & $\begin{array}{l}F E V_{1} \\
\text { (1) }\end{array}$ & $\begin{array}{l}F V C \\
\text { (1) }\end{array}$ & $\begin{array}{l}\mathrm{PaO}_{2} \\
(\mathrm{kPa})\end{array}$ & $\begin{array}{l}\mathrm{PaCO}_{2} \\
(\mathrm{kPa})\end{array}$ \\
\hline \multicolumn{8}{|c|}{ COR PULMONALE GROUP } \\
\hline 1 & 68 & $67 \cdot 5$ & Moduretic 2 & $0 \cdot 78$ & 1.46 & $5 \cdot 3$ & $5 \cdot 7$ \\
\hline 2 & 67 & $78 \cdot 8$ & Burinex K 1 & 0.46 & $2 \cdot 15$ & 6.9 & $6 \cdot 1$ \\
\hline 3 & 47 & $68 \cdot 8$ & None & 0.50 & 2.09 & $5 \cdot 3$ & $7 \cdot 8$ \\
\hline 4 & 78 & 95.5 & Frumil 3 & 0.71 & $1 \cdot 14$ & $8 \cdot 7$ & $6 \cdot 0$ \\
\hline 5 & 55 & $122 \cdot 0$ & Frumil 2 & $1 \cdot 27$ & $3 \cdot 40$ & 6.4 & $7 \cdot 8$ \\
\hline 6 & 76 & 66.0 & Frusemide $40 \mathrm{mg}$ & 0.51 & $1 \cdot 18$ & $6 \cdot 3$ & $6 \cdot 6$ \\
\hline 7 & 76 & $68 \cdot 0$ & Frumil 2 & 0.63 & $1 \cdot 15$ & $7 \cdot 0$ & $6 \cdot 7$ \\
\hline 8 & 71 & 93.0 & Frumil 2 & 0.76 & 1.96 & $5 \cdot 1$ & $8 \cdot 0$ \\
\hline 9 & 66 & $101 \cdot 0$ & Burinex K 1 & 1.04 & $2 \cdot 79$ & $7 \cdot 4$ & 6.5 \\
\hline 10 & 64 & $55 \cdot 7$ & None & $0 \cdot 60$ & $2 \cdot 16$ & $5 \cdot 4$ & $6 \cdot 0$ \\
\hline $\begin{array}{l}\text { Mean } \\
\text { SE }\end{array}$ & $\begin{array}{r}66 \cdot 8 \\
3 \cdot 1\end{array}$ & $\begin{array}{r}81 \cdot 7 \\
6 \cdot 2\end{array}$ & & $\begin{array}{l}0.73 \\
0.08\end{array}$ & $\begin{array}{l}1.95 \\
0.22\end{array}$ & $\begin{array}{l}6 \cdot 4 \\
0 \cdot 4\end{array}$ & $\begin{array}{l}6 \cdot 7 \\
0 \cdot 3\end{array}$ \\
\hline \multicolumn{8}{|c|}{ CONTROL GROUP } \\
\hline 1 & 63 & $67 \cdot 5$ & Burinex K 1 & 1.07 & $2 \cdot 66$ & $10 \cdot 1$ & $4 \cdot 8$ \\
\hline 2 & 63 & $75 \cdot 0$ & Bendrofluazide $5 \mathrm{mg}$ & 0.77 & 1.68 & $9 \cdot 1$ & $4 \cdot 1$ \\
\hline 3 & 61 & $51 \cdot 5$ & None & 1.07 & $3 \cdot 14$ & $8 \cdot 3$ & $5 \cdot 4$ \\
\hline 4 & 58 & $77 \cdot 0$ & None & 1.48 & $3 \cdot 32$ & $9 \cdot 8$ & $4 \cdot 8$ \\
\hline 5 & 66 & $66 \cdot 0$ & None & $0 \cdot 74$ & $2 \cdot 87$ & $8 \cdot 3$ & $5 \cdot 4$ \\
\hline 6 & 68 & $62 \cdot 0$ & None & $0 \cdot 74$ & $1 \cdot 56$ & $7 \cdot 5$ & 5.9 \\
\hline 7 & 69 & $74 \cdot 0$ & None & 1.53 & $4 \cdot 32$ & $11 \cdot 0$ & $4 \cdot 8$ \\
\hline 8 & 62 & $92 \cdot 9$ & None & 0.80 & $1 \cdot 70$ & $7 \cdot 4$ & $6 \cdot 3$ \\
\hline 9 & 68 & $40 \cdot 0$ & None & 1.07 & 2.92 & $6 \cdot 5$ & $5 \cdot 8$ \\
\hline 10 & 55 & $61 \cdot 5$ & None & 1.40 & $3 \cdot 30$ & $8 \cdot 2$ & $5 \cdot 4$ \\
\hline Mean & $63 \cdot 3$ & $66 \cdot 7$ & & $1.07^{\star}$ & $2 \cdot 75^{\star}$ & $8 \cdot 6^{\star \star}$ & $5 \cdot 3^{\star \star}$ \\
\hline SE & $1 \cdot 4$ & $4 \cdot 4$ & & 0.09 & $0 \cdot 26$ & 0.4 & $0 \cdot 2$ \\
\hline
\end{tabular}

^Frumil: frusemide $40 \mathrm{mg}$ and amiloride $5 \mathrm{mg}$; Burinex $\mathrm{K}$ : bumetanide $0.5 \mathrm{mg}$ and potassium $7.7 \mathrm{mmol}$; Moduretic: amiloride $5 \mathrm{mg}$ and hydrochlorothiazide $50 \mathrm{mg}$.

Significance in comparison with the cor pulmonale group: ${ }^{\star} \mathrm{p}<0.05,{ }^{\star \star} \mathrm{p}<0.01$ (unpaired $t$ test).

Table 2 Baseline plasma and urinary sodium concentrations and urine volumes and sodium excretion during the test with calculated fractional sodium reabsorption, free water clearance, and four and half hour creatinine clearance

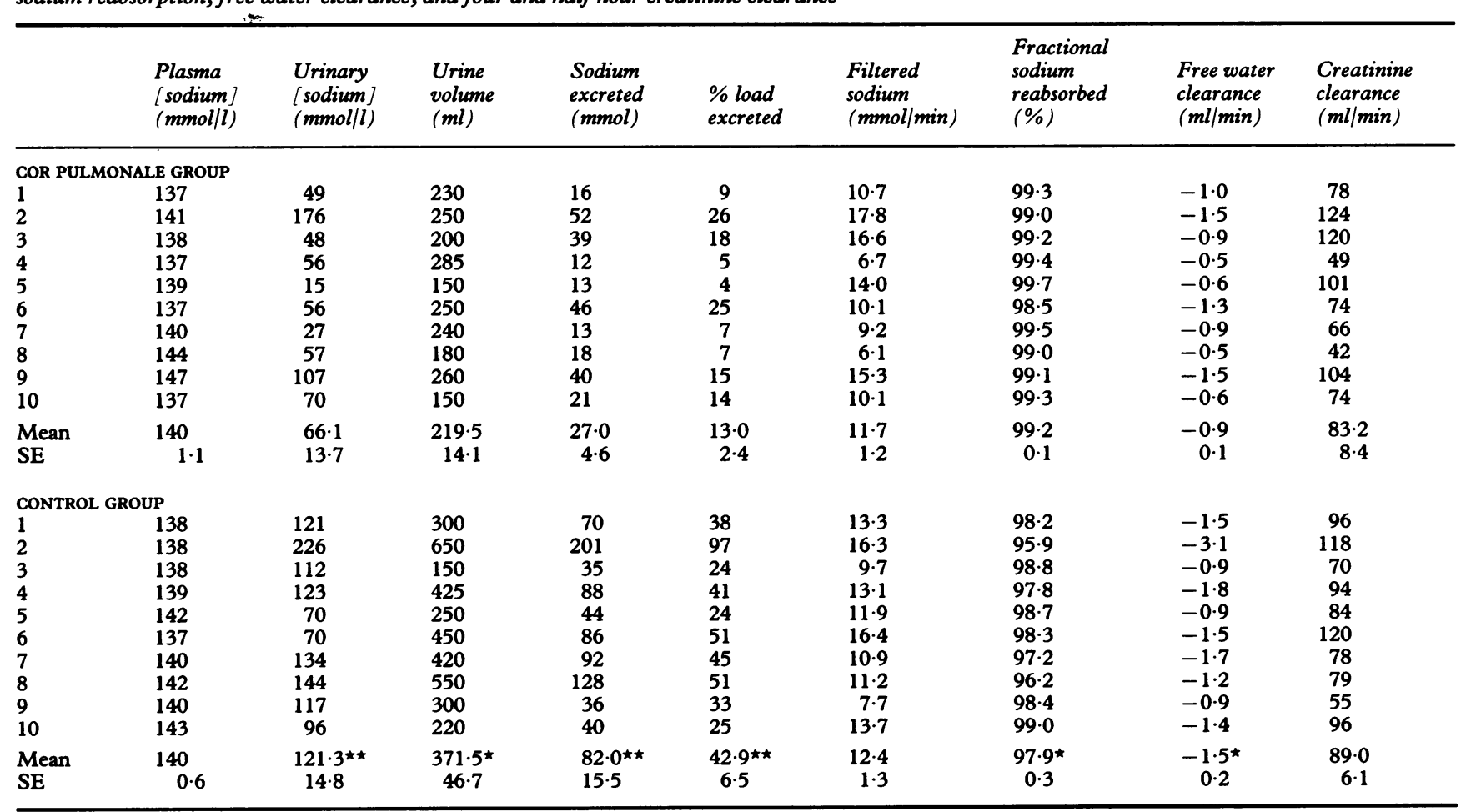

Significance in comparison with the cor pulmonale group: ${ }^{\star} \mathrm{p}<0.05,{ }^{\star \star} \mathrm{p}<0.01$ (unpaired $t$ test). 
sodium concentration was lower in the group with cor pulmonale than in the group without $(\mathrm{p}<0.01)$ (table 2). The mean (SE) four hourly urine sodium excretion was $27(4.6) \mathrm{mmol}$ in the cor pulmonale group ( $13 \%$ of the load) and $82(15.5) \mathrm{mmol}$ in the patient without cor pulmonale ( $43 \%$ of the load); this difference was significant $(p<0.01)$. The volume of urine produced during the test was $220(14) \mathrm{ml}$ in the cor pulmonale group and $372(47) \mathrm{ml}$ in the control group $(p<0.05)$. The four and a half hour creatinine clearance was similar in the two groups (83.2 (8.4) $v 89(6 \cdot 1) \mathrm{ml} / \mathrm{min}$. Although filtered sodium was similar in the two groups, fractional sodium reabsorption was greater in the group with cor pulmonale $(99.2 \%(0 \cdot 1 \%) v$ $97.9 \%(0.3 \%)$ in the control group $(p<0.05))$. More water was reabsorbed in the kidneys of

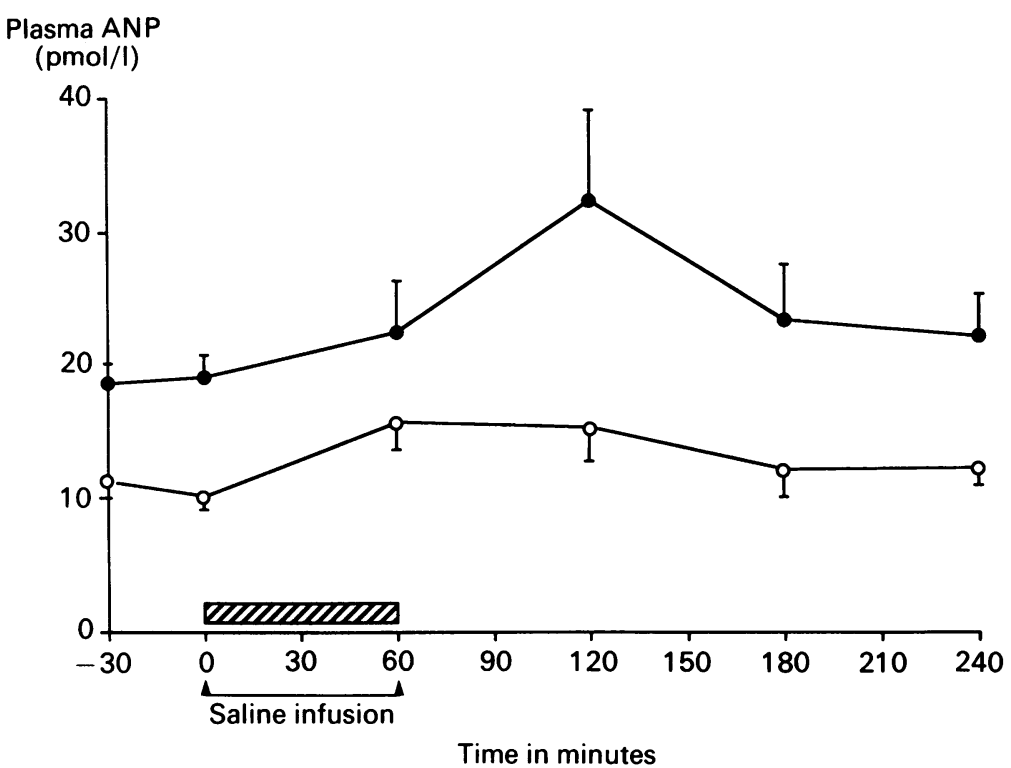

Figure 1 Plasma atrial natriuretic peptide concentrations in pmol/l before, during, and for three hours after a $2.7 \%$ saline infusion $(6 \mathrm{ml} / \mathrm{kg}$ over one hour) in 10 patients with cor pulmonale (-O-) and 10 control patients (- -$)$. The normal range is up to $12 \mathrm{pmol} / \mathrm{l}$.

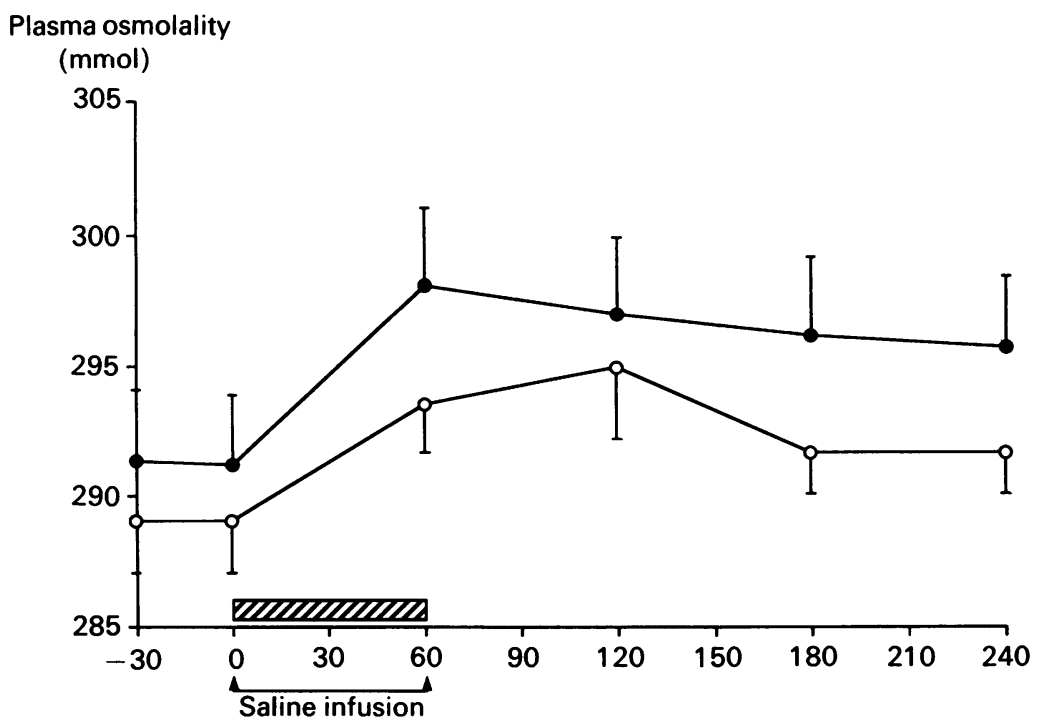

Time in minutes

Figure 2 Plasma osmolality before, during, and for three hours after a $2 \cdot 7 \%$ saline infusion ( $6 \mathrm{ml} / \mathrm{kg}$ over one hour) in 10 patients with pulmonale (-) -) and 10 control patients (-O-). the patients without cor pulmonale ( $p<0.05$ ), as indicated by the more negative free water clearance.

At time zero mean plasma atrial natriuretic peptide values were higher in the patients with cor pulmonale (19.1 (1.6) pmol/1) than in those without $(10.2(0.7) \mathrm{pmol} / \mathrm{l} ; \mathrm{p}<0.01)$. The mean peak rise in atrial natriuretic peptide was $13(8 \cdot 0) \mathrm{pmol} / \mathrm{l}$ in those with cor pulmonale and $5.5(2.3) \mathrm{pmol} / 1$ in the others $(\mathrm{p}<0.05)$. Atrial natriuretic peptide concentrations during the study are shown in figure 1.

There were no significant differences in plasma or urinary osmolality, serum sodium concentration, or blood pressure between the groups at any time in the study. The serum sodium concentration returned to baseline values by the end of the study. Figure 2 shows the plasma osmolality responses.

\section{Discussion}

Our study shows that patients with chronic obstructive airways disease and cor pulmonale have raised plasma atrial natriuretic peptide concentrations whereas hypoxaemic patients without cor pulmonale have atrial natriuretic peptide concentrations at the upper limit of the normal range (12 pmol/1 for our assay). A previous study found atrial natriuretic peptide concentrations in patients with chronic obstructive airways disease similar to those found in this study but no correlation between plasma atrial natriuretic peptide concentration and haemodynamic variables. ${ }^{3}$ Our dynamic stress test, a more sensitive method of detecting abnormalities in hormone release than random sampling, showed a difference in response between oedematous and non-oedematous patients.

By comparison with patients with chronic obstructive airways disease who had no history of cor pulmonale those with cor pulmonale had an impaired ability to handle a salt load, despite raised concentrations of plasma atrial natriuretic peptide and an appropriate atrial natriuretic peptide response to the stress of hypertonic saline infusion. These data suggest that atrial natriuretic peptide release is appropriate in cor pulmonale but that the renal response to plasma atrial natriuretic peptide is impaired.

The rise in plasma atrial natriuretic peptide in response to a saline load in our patients with chronic obstructive airways disease who did not have cor pulmonale was relatively normal, ${ }^{11}$ whereas that in the group with cor pulmonale appeared to be exaggerated.

Urine volume and sodium excretion, fractional sodium reabsorption, and free water clearance in our non-oedematous patients'were similar to the findings in the control patients studied by Farber et al, who gave a similar saline infusion. Our cor pulmonale group was similar to their group with respiratory failure $^{812} 13$ in having both hypercapnia and oedema. Sodium and water excretion and the abnormalities in sodium reabsorption and free water clearance were similar in all the studies. Their results and ours could be explained by an 
increased sodium reabsorption in the proximal tubule, which limits the volume of urine delivered to the more distal segments, where free water is generated for excretion. A similar mechanism may account for sodium and water retention in ascites due to cirrhosis ${ }^{14}$ and in congestive cardiac failure. ${ }^{15}$ Although diuretic induced sodium depletion reduces excretion of a water load by the same mechanism, ${ }^{14}$ diuretic usage is unlikely to account for our results as no patients were sodium deficient, diuretics were stopped for three days before the study, and the test used a hypertonic saline rather than water load.

The lower baseline urinary sodium excretion in the group with cor pulmonale could be due to the disease or to diuretic withdrawal. Although we cannot exclude the latter, we believe the former explanation is correct for several reasons. Firstly, similar results were seen in the study by Farber et al in patients who were not taking diurectics. ${ }^{8}$ Secondly, the two patients with cor pulmonale who were not currently taking diurectics also had a low baseline urinary sodium excretion. The two patients without cor pulmonale who were taking diurectics (withdrawn for three days as in the cor pulmonale group) had higher rather than lower urinary sodium concentrations than the other patients in their group. Thirdly, the impairment of sodium excretion was not related to the dose of diuretics.

The use of diuretics for treating cor pulmonale provides a methodological problem that is difficult to avoid in this type of study. Long term withdrawal of diuretics may lead to clinical deterioration and is not ethical. We stopped diuretics for three days as this is acceptable to patients and has not led to clinical deterioration in this or previous studies. Prior diuretic usage does not invalidate our finding that a failure of atrial natriuretic peptide release is not the cause of sodium and water retention in cor pulmonale.

Our patients were clinically stable, so possibly a failure in atrial natriuretic peptide release could occur during acute respiratory decompensation. This is unlikely as all our patients with cor pulmonale had oedema and a raised concentration of atrial natriuretic peptide. The increase in pulmonary artery pressure during an acute exacerbation would tend to increase rather than decrease atrial natriuretic peptide secretion. ${ }^{2}$

Other hormonal abnormalities have been described in cor pulmonale, ${ }^{8}$ including increased concentrations of aldosterone and increased plasma renin activity, which are suppressed appropriately during a hypertonic saline load. Concentrations of antidiuretic hormone are high in relation to plasma osmolality, though they rise as expected during a saline infusion. In cor pulmonale hormonal mechanisms appear to be activated in an attempt to maintain homeostasis in the face of a renal impairment of sodium handling.

Although the glomerular filtration rate may be reduced in cor pulmonale, ${ }^{16}$ the reduction is insufficient to account for the degree of salt and water retention; $;^{17}$ and the glomerular filtration rate does not correlate with the impaired ability to excrete a salt and water load. ${ }^{81819}$ Other studies have shown a relatively normal glomerular filtration rate in cor pulmonale $e^{1820}$ and a low effective renal plasma flow. ${ }^{71820}$ The resultant increase in filtration fraction will increase sodium reabsorption, as will hypercapnic acidosis due to the increased $\mathrm{H}^{+}$secretion.

The complex natriuretic effects of atrial natriuretic peptide are not fully determined. In saline loaded rats pretreatment with a monoclonal antibody to atrial natriuretic peptide abolishes the natriuresis. ${ }^{21}$ Atrial natriuretic peptide infusion in normal man increases the plasma atrial natriuretic peptide concentration and produces a long lasting natriuresis. The concentrations of atrial natriuretic peptide seen during such infusions are associated with an increase in glomerular filtration rate and a decrease in effective renal plasma flow. ${ }^{22}$ Natriuresis may occur in response to altered intrarenal haemodynamics, ${ }^{23}$ leading to medullary washout. ${ }^{24}$ In cor pulmonale, where the effective renal plasma flow is low, a further reduction would tend to exacerbate sodium retention. Although atrial natriuretic peptide increases lithium clearance, ${ }^{25}$ the lack of atrial natriuretic peptide receptors in the proximal tubule makes it unlikely that atrial natriuretic peptide has a direct action at this site. Initial claims that it antagonised the effects of angiotensin II on the proximal tubule ${ }^{26}$ have not been confirmed. ${ }^{27}$

The blunted natriuretic response to atrial natriuretic peptide infusion in oedematous animal models of heart failure, cirrhotic ascites, and the nephrotic syndrome is fully restored by prior renal denervation. Augmented renal sympathetic tone may decrease the effect of atrial natriuretic peptide by increasing the proximal renal tubular sodium reabsorption. ${ }^{28}$ The effect of atrial natriuretic peptide may also be diminished by a reduction in renal perfusion pressure. ${ }^{29}$ Further investigation is needed to determine whether these or other mechanisms are responsible for the reduced renal response to atrial natriuretic peptide in cor pulmonale.

In conclusion, patients with cor pulmonale have an impaired ability to excrete a hypertonic saline load despite raised basal concentrations of atrial natriuretic peptide and a normal physiological release of atrial natriuretic peptide in response to saline loading. Defective atrial natriuretic peptide release is not a cause of oedema in hypoxaemic cor pulmonale.

JST was supported by the British Lung Foundation. Our thanks go to our diagnostic nursing team, particularly Mrs Margaret Ashley and Mrs Margaret Dugas, and to the staff in the respiratory function laboratory. The biochemical results were measured by Dr R Forrest in the clinical chemistry department
at the Royal Hallamshire Hospital.

1 Sagnella GA, Markandu NM, Shore AC, MacGregor GA Effects of changes in dietary sodium intake and saline infusion on immunoreactive atrial natriuretic peptide in human plasma. Lancet 1985;ii:1208-11.

2 Morice AH, Pepke-Zaba J, Brown MJ, Thomas P, Higenbottam $T$. Atrial natriuretic peptide in pulmonary hypertension. Eur Respir J 1990;3:910-3.

3 Winter RJD, Davidson AC, Treacher D, Rudd RM, Anderson JV, Meleagros L, et al. Atrial natriuretic peptide concentrations in hypoxic secondary pulmonary hyper- 
tension; relation to haemodynamic and blood gas variables and response to supplemental oxygen. Thorax 1989; 44:58-62.

4 Morice AH, Pepke-Zaba J, Loysen E, Lapworth R, Ashby $M$, Higenbottam $T$, et al. Low dose infusion of atrial natriuretic peptide causes salt and water excretion in normal man. Clin Sci 1988;74:359-63.

5 Renzetti AD, McClement JH, Litt BD. The Veterans' Administration co-operative study of pulmonary function. III. Mortality in relation to respiratory function in chronic obstructive pulmonary disease. Am J Med 1966; 41:115-9.

6 MacNee W, Xue QF, Hannan WJ, Flenley DC, Adie CJ, Muir AL. Assessment by radionuclide angiography of right and left ventricular function in chronic bronchitis and emphysema. Thorax 1983;38:494-500.

7 Platts MM, Hammond JDS, Stuart-Harris $\mathbf{C H}$. A study in patients with chronic bronchitis. $Q J$ Med 1960;29. 559-74.

8 Farber MO, Roberts LR, Weinberger MH, Robertson GL, Fineberg NS, Manfredi F. Abnormalities of sodium and water handling in chronic obstructive lung disease. Arch water handling in chronic obs
Intern Med 1982;142:1326-30.

9 Crandall ME, Gregg CM. In vitro evidence for an inhibitory effect of atrial natriuretic peptide on vasopressin release. Neuroendocrinology 1986;44:439-45.

10 Maack T, Marion DN, Camargo MJF. Effects of atrial natriuretic factor on blood pressure, renal function and the renin-aldosterone system in dogs. Am J Med 1984; 77:1069-75.

11 Anderson JV, Donckier J, McKenna WJ, Bloom SR. The plasma release of atrial natriuretic peptide in man. Clin Sci 1986;71:151-5.

12 Reihman DH, Farber MO, Weinberger M, Henry DP, Fineberg NS, Dowdeswell IRG, et al. Effects of hypoxaemia on sodium and water excretion in chronic obstructive lung disease. Am J Med 1985;78:87-94.

13 Farber MO, Weinberger MH, Robertson GL, Fineberg NS The effects of angiotensin converting enzyme inhibition on sodium handling in patients with advanced chronic obstructive pulmonary disease. Am Rev Respir Dis 1987; 136:862-6.

14 Schedl HP, Bartter FC. An explanation for and experimental correction of abnormal water diuresis in cirrhosis. J Clin correction of abnormal
Invest 1960;39:248-61.

15 Bell NH, Schedl HP, Bartter FC. An explanation for abnormal water retention and hypoosmolality in conges- tive heart failure. Am J Med 1964;36:351-60.

16 Stuart-Harris CH, MacKinnon J, Hammond JDS, Smith WD. The renal circulation in chronic pulmonary disease and pulmonary heart failure. $Q J$ Med 1956;99:389-405.

17 Aber GM, Bayley TJ, Bishop JM. Inter relationships between renal and cardiac function and respiratory gas exchange in obstructive airways disease. Clin Sci 1963; 25:159-70.

18 Bardsley PA, Stewart AG, Howard P. Plasma aldosterone and antidiuretic hormone during oral water loading in stable cor pulmonale. Eur Respir J 1988;1(suppl 1):151.

19 White RJ, Woodings DF. Impaired water handling in chronic obstructive airways disease. BMJ 1971;ii:561-3.

20 Oliver RM, Peacock AJ, Fleming JS, Waller DG. Renal and pulmonary effects of angiotensin converting enzymes in chronic hypoxic lung disease. Thorax 1989;44:513-5.

21 Hirth C, Stasch J-P, John A, Kazda S, Morich F. The renal response to acute hypervolaemia is caused by atrial natriuretic peptides. J Cardiovasc Pharmacol 1986;8: 268-75.

22 Janssen WMT, Zeeuw D, Hem GK van der, Jong PE de. Atrial natriuretic peptide-induced decreases in renal blood flow in man: implications for the natriuretic mechanism. Clin Sci 1989;77:55-60.

23 Kiberd BA, Larson TS, Robertson CR, Jamison RL. Effect of atrial natriuretic peptide on vasa recta blood flow in the rat. Am J Physiol 1987;252:F1112-7.

24 Davis CL, Briggs JP. Effect of atrial natriuretic peptide on renal medullary solute gradients. Am J Physiol 1987; 253:F679-84.

25 Brier ME, Brier RA, Luft FC, Aronoff GR. Kinetics and pharmacodynamics of atrial natriuretic peptide and lithium clearance in the isolated rat kidney. $J$ Pharmacol Exp Ther 1987;243:868-73.

26 Harris PJ, Thomas D, Morgan TO. Atrial natriuretic peptide inhibits angiotensin stimulated proximal tubular peptide inhibits angiotensin stimulated proximal tubular

27 Liu F-Y, Cogan MG. Atrial natriuretic factor does not inhibit basal or angiotensin II-stimulated proximal transport. Am J Physiol 1988;255:F434-7.

28 DiBona GF, Koepke JP. Elevated renal nerve activity attenuates atrial natriuretic peptide natriuresis in edematous states [abstract]. In: Proceedings of the 10th International Congress of Nephrology. Vol 10. London: Ballière Tindall, 1987:209.

29 DiBona GF. The functions of the renal nerves. Rev Physiol Biochem Pharmacol 1982;94:176-81. 